\title{
One Time New Surgical Correction for Severe Upper Eyelid Acquired Ptosis
}

\begin{abstract}
GHEORGHE NODITI'*, MIHAIL COJOCARU ${ }^{1}$, DAN GRIGORESCU2, GEORGE NODITI ${ }^{3}$
${ }^{1}$ Victor Babes University of Medicine and Pharmacy, Emergency County Hospital Timisoara,Department of Plastic and Reconstructive Surgery, 2 Eftimie Murgu Sq.,300041, Timisoara, Romania

${ }^{2}$ Transilvania University Brasov, Faculty of Medicine, Emergency County Hospital Brasov, 29 Eroilor Blvd., 500036, Brasov, Romania

${ }^{3}$ Victor Babes University of Medicine and Pharmacy, Department of Surgery II, Emergency County Hospital Timisoara, 2 Eftimie Murgu Sq., 300041,Timisoara, Romania

Palpebral ptosis is a condition caused by different congenital and acquired pathologies. Seeing difficulty due to the visual field obstruction, prefrontal headaches due to chronic use of the frontalis muscle in an attempt to lift the eyelids and cosmetic deformity are the main complaints of the patients. The surgical correction of the ptosis can be challenging. According to the preoperative evaluation, the most appropriate technique should be used to maximize the postoperator result. We describe a new surgical approach for severe upper eyelids acquired ptosis consisting in reanimation of both eyelids by using the neighboring active muscle. We considered the patient a good candidate for the new surgical approach we introduce as one time operative procedure. The result was a normal palpebral fissure for both eyes. The advantage of this approach consists in performing one time surgery followed by immediate postoperative mobilization of the upper eyelids which determine the recovery of the upper lids motility by further self-control.
\end{abstract}

Keywords: palpebral ptosis, isual field obstruction, upper eyelids

Palpebral ptosis is a common condition resulting from the dysfunction of one or both upper eyelid retractors. It may be caused by various pathologies, both congenital and acquired. Mechanical ptosis due to dermatochalasis and brow ptosis is often seen in the aging population and can accompany many of the other types of ptosis. Myogenic ptosis, aponeurotic ptosis, neurogenic ptosis, and neuromyogenic ptosis (eg, ocular myasthenia) can all present in adults and present rarely in children as well [1] The most common type of ptosis in adults is involutional ptosis secondary to acquired dehiscence or detachment of the elevator aponeurosis from the tarsus [1]. Depending on the degree of ptosis, the patient symptoms may range from an asymptomatic subtle cosmetic defect to significant visual deficits. Drooping of the upper eyelids is one of the most common complaints [2]. Other related complaints include seeing difficulty due to visual field obstruction and prefrontal headaches due to chronic use of the frontalis muscle in an attempt to lift the eyelids [1]. Ptosis causes also an apparent cosmetic deformity.

Surgical treatment of palpebral ptosis is complex and requires precise diagnosis and indications for surgery related to clinical examination and pathogenesis. The microcirculation suffered changes and can be monitored with the Moor laser Doppler line scanner to see adjustments in the micro-vascularity of the region in the healing period [2].

Ptosis surgery can be challenging for even the most experienced eye and plastic surgeon. The rate of reoperation in most series of acquired ptosis varies from 5 to 35\% [3-5]. Detailed preoperative assessment and intraoperative anatomic dissection with respect to tissue planes and hemostasis should minimize reoperations and maximize postoperative results.

In this paper we will discuss a new technical approach for severe bilateral acquired ptosis.

\section{Experimental part}

Materials and methods

We are presenting a new one time technical approach suitable for severe bilateral acquired palpebral ptosis of the upper eyelid.

The preoperative evaluation consisted in detailed patient history and local examination. The four important measurements: interpalpebral fissure height, upper lid margin to corneal reflex distance (MRD1), levator function, and upper lid crease position have been assessed and recorded with the patient looking in primary position. Photographs of the patients pre, intra and postoperative have been made, after getting the w ritten consent.

The technical procedure consists in creating a muscular plan from a fascicle of upper lid orbicular that is advanced superior to the elevator of eye brow. After identification of the orbicular muscle a fascicle from the orbicular muscle with bipedicled vascularization is isolated. An isosceles triangle shape is formed. Upper triangle top is fixed to the upper eyelid elevator. Wallpapering the fascicle on the eye brow elevator determine an integral unit with fixed points. While moving the elevator of the eye brow the palpebral fissure is opening. The result is a normal pal pebral fissure. The procedure was done as one time surgery for both eyes.

Case report. Patient of 58 years, with Miastenia Gravis and bilateral eyelid ptosis.

Preoperative evaluation for both eyes are presented in figure 1 and 2 . The local measurements were:

- palpebral fissure bilateral $2 \mathrm{~mm}$

- levator function bilateral less than $4 \mathrm{~mm}$

- upper lid crease position bilateral $>8 \mathrm{~mm}$

- the position of the lower eyelids are normal.

General clinical examination and biological parameters have been evaluated prior to surgical procedure. Local anaesthetic agents are drugs that are administrated to patient in order to cause a reversible loss of sensation 


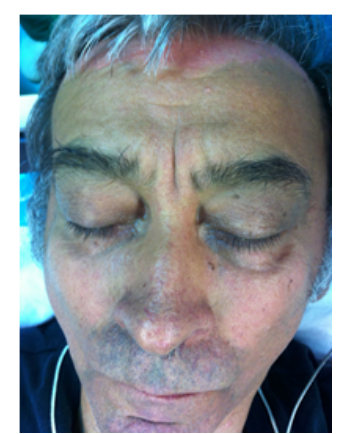

Fig. 1. Preoperator evaluation

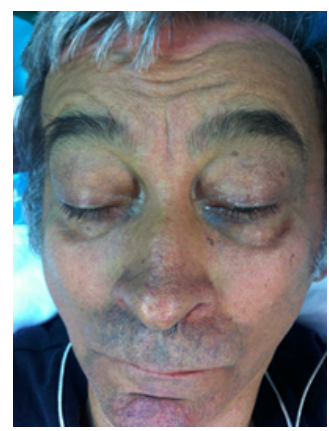

Fig. 2. Preoperator evaluation

for a certain region of the body while maintaining consciousness [6]. In our case general anesthesia has been used to preserve the local anatomical plans.

Skin incisions was made at $2 \mathrm{~mm}$ of ciliay edge of the upperlid.

The next photos are showing intraoperator aspects of the most important steps (figs. 3, 4, 5, 6).

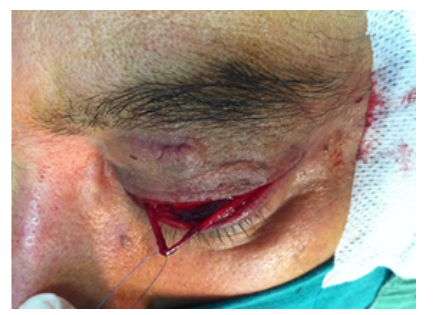

Fig. 3. Identification of the orbicular muscle

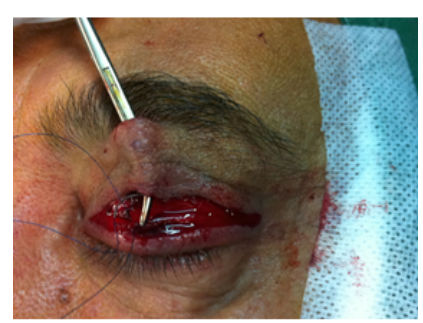

Fig. 4. Subcutaneous tunneling of the orbicular fascicle

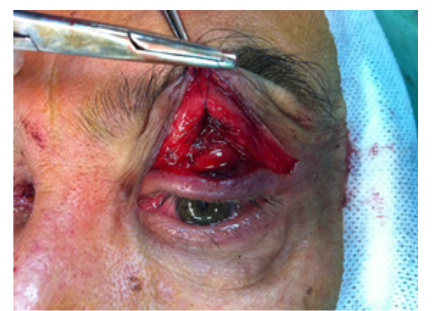

Fig. 5. Fixing the orbicular muscular fascicle to the eye brow elevators bilateral.

For good cosmetic results, the symmetry of both eyes surgery has been carefully controlled. The skin was closed with several 6-0 absorbable interrupted sutures bilaterally.

\section{Results and discussions}

The immediate postoperator evaluation showed good functional and cosmetic results. No complications occurred. The pictures (figs. 7,8 and 9) bellow are showing the immediate results and after 14 days.

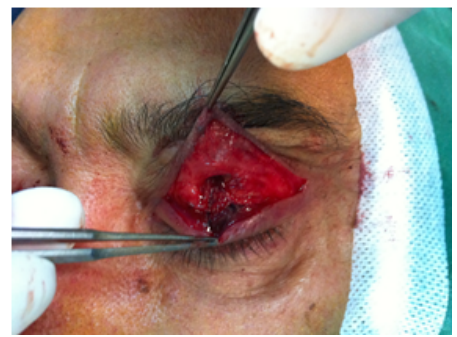

Fig. 6. Wallpapering the fascicle on the eye brow elevators bilateral

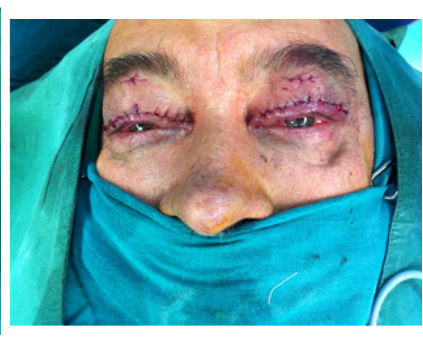

Fig. 7. Immediate result after surgery.

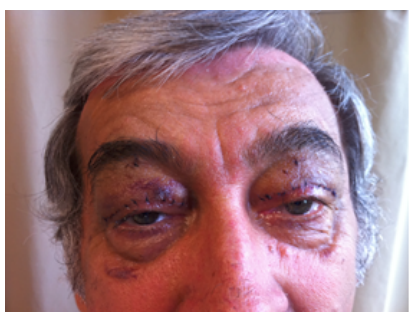

Fig. 8. Follow up. Result at 7 days postoperative

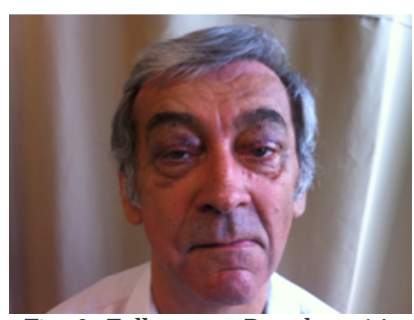

Fig. 9. Follow up. Result at 14 days postoperative
The severe palpebral ptosis acquired in different pathologic circumstances can have a significant impact for the patient. The visual field obstruction when bilaterally together with the cosmetic impairment are the main complaints of the patients. Many surgical techniques have been described for the repair of palpebral ptosis. Tarsomyectomy (Fasanella-Servat Procedure) is a technically simple and predictable procedure suitable for young patients with mild lid asymmetry [7]. Posterior Muller's Muscle/Conjunctival Resection (Putterman Mullerectomy Procedure) is an alternative procedure for minimal ptosis ( $2 \mathrm{~mm}$ or less) and good levator function. It is a technically difficult procedure with limited amount of eyelid lift [8-10]. Levator Aponeurotic Advancement Procedure is used in cases of fair to good levator function [11]. This technique results in the shortening of the levator complex. Frontalis Suspension Techniques are reserved for patients with poor levator function (0 to $4 \mathrm{~mm}$ ) and intact frontalis muscle. This technique involves elevating the eyelid by suspending the tarsus to the frontalis muscle $[12,13]$.

Bellinvia et all.,[14] describe their technique for upper blepharoplasty, which includes an extended cutaneous excision that permits good correction of lateral hooding, reducing the need for browpexy or browlifting.

Correction of the retraction by levator lengthening using the pretarsal tissue is simpler to execute, measurable during surgery, and easy to adjust, and offers high predictability in its result [15].

Our experience with shortening the levator aponeurosis by an anterior approach through an eyelid crease incision with or without concomitant blepharoplasty [16]. Despite the limitations of our study, we believe that external levator advancement is effective in long-term correction of severe aponeurotic ptosis.

In accordance with a recent study [17 - 20], external superior levator advancement for blepharoptosis is an effective procedure in establishing good long-term eyelid position and symmetry, with reported success rates of $85 \%$.

\section{Conclusions}

We have presented a severe bilateral acquired ptosis that has been successfully solved in one time surgery by using this new surgical approach.

The advantages of this new approach consisted in performing one operative time and immediate mobilization of the upper lids which determines the self-control of both eyelids mobility and palpebral fissures in physiological parameters.

A detailed knowledge of eyelid anatomy coupled with a comprehensive history and preoperator evaluation are the prerequisites for proper surgical planning as a key for good surgical outcomes. 
We consider that this new surgical approach is suitable for severe upper eyelid ptosis acquired in different pathologic situations.

\section{Refernces}

1. SCHAEFER AJ, SCHAEFER DP. Classification and correction of ptosis. In: Stew artWB, editor.Surgery of the eyelid, orbit, and lacrimal system. American Academy of Ophthalmology;1994. p. 84-133.

2. NODITI GH., TODEA C.,Laser Doppler Imaging - as a Non-invasive Method for Assesing Regional Microcirculation when using Plastic Materials for Guided Healing, Mat. Plast., 50, no. 1, 2013, p. 40 3. MELTZER MA, ELAHI E, TAUPEKA P, FLORES E.A simplified technique of ptosis repair using a singleadjustable suture. Ophthalmology 2001; volume 108, p:1889-92.

4. MCCULLEY TJ, KERSTEN RC, KULWIN DR, FEUER WJ. Outcome and influencing factors of external levator palpebrae superioris advancement for blepharoptosis. Ophthal Plast Reconstr Surg 2003; volume 19, p:388-93.

5. WHITEHOUS GM, GRIGG JR, MARTIN FS. Congenital ptosis; results of surgical management.Aust N Z J Ophthalmol 1995; volume 23, p:309-14.

6. NODITI GH, LEDETI I, SIMU GEORGIANA, SUTA MARIA-LENUTA, ONETIU DANIELA, FULIAS A., Microwave - assisted synthesis of local anesthetic procaine from benzocaine Rev. Chim. (Bucharest), 65, no.1, 2014, p. 65

7. FOX SA. Modified Fasanella-Servat procedure for ptosis. Arch Ophthalmol 1975; volume 93, p:639-640

8. ARTHURS BP, DELLA ROCCA RC. Entropian. In: Della Rocca RC, Bedrossian EH Jr, ARTHURS BP, eds. Ophthalmic Plastic Surgery: Decision Making and Techniques. New York: McGraw-Hill; 2002, p: 77-89

9. PUTTERMAN AM, URIST MJ. Upper eyelid retraction after glaucoma filtering procedures. Ann Ophthalmol 1975; volume 7, p:263-266 10. PUTTERMAN AM, FETT DR. Muller's muscle in the treatment of upper eyelid ptosis: a ten-year study. Ophthalmic Surg 1986; volume $17, p: 354-360$
11. BERLIN AJ, VESTAL KP. Levator aponeurosis surgery: a retrospective review. Ophthalmology 1989; volume 96, p:1033-1036 12. CRAWFORD JS. Repair of ptosis using frontalis muscle and fascia lata: a 20-year review. Ophthalmic Surg 1977; volume 8, p:31- 40 13. LEONE CR J R, SHORE JW, VAN GEMERT JV. Silicone rod frontalis sling for the correction of blepharoptosis. Ophthalmic Surg 1981; volume 12 , p:881-88.

14. BELLINVIA G, KLINGER F, MAIONE L, BELLINVIA P. Upper lid blepharoplasty, eyebrow ptosis, and lateral hooding. Aesthet Surg J. 2013 Jan. J ournal 33(1), p: 24-30.

15. CHO IC, KANG J H, KIM KK. Correcting upper eyelid retraction by means of pretarsal levator lengthening for complications following ptosis surgery. Plast Reconstr Surg. 2012 Jul. volume 130(1), p:73-81. 16. INNOCENTI, A., MORI, F., MELITA, D., DREASSI, E., INNOCENTI, M. Effects of orbicularis oculi flap anchorage to the periosteum of the upper orbital rim on the lower eyelid position after transcutaneous blepharoplasty: statistical analysis of clinical outcomes. J Plast Reconstr Aesthet Surg. 2016; volume 16, p:30480-30486 DOI: http:// dx.doi.org/10.1016/j.bjps.2016.10.01917.

17. ELBAKARY MA. Posterior approach levator aponeurosis advancement in aponeurotic ptosis repair. Delta J Ophthalmol. 2015; volume $16, \mathrm{p}: 32-36$.

18. PETRESCU, H. P.,DINU, G., NODITI, G., BERCEANU-VADUVA, M., BRATU, D.C., VERMESAN, D., Experimental morphologic and radiologic study of the integration of bone grafts into the host tissue and of the dynamics of the graft-receptor interface, Romanian J ournal of Morphology and Embryology, Volume: 55, Issue: 2, Supplement: S, pp: 607-612, 2014

19. CRAINICEANU, Z., EMILIA, IANE E., MATUSZ, P., BLOANCA, V., SELEACU, E., NARAD, V., NARAD, G., NODITI G., BRATU, T., Method of Titanium Plate Use for Morphological and Functional Human Face Recontruction, Mat. Plast., 53, no. 3, 2016, p. 518

20. ROSU, S.,PETER F., TATU, R.F., ABS 3D Printed Facial Study Model Using Hermite Matrix Interpolation for Manufacturing Facial Epistasis, Mat. Plast., 51, no. 3, 2014, p. 290

Manuscript received: 21.04 .2017 